\title{
SPOSÓB TESTOWANIA ZNAJOMOŚCI ASPEKTU W PAŃSTWOWYCH EGZAMINACH CERTYFIKATOWYCH Z JEZYKA POLSKIEGO JAKO OBCEGO NA POZIOMIE B1 W ŚWIETLE NOWYCH BADAŃ NAD DOKONANOŚCIAৃ/NIEDOKONANOŚCIĄ CZASOWNIKA
}

\begin{abstract}
Slowa kluczowe: aspekt czasownika, egzamin certyfikatowy, poprawność gramatyczna, podejście kognitywne, wykładnik kontekstowy, wymienność partnerów aspektowych

Streszczenie. Artykuł dotyczy sposobu sprawdzania stopnia opanowania zagadnienia aspektu polskiego czasownika przez zdających państwowe egzaminy certyfikatowe z języka polskiego jako obcego na poziomie B1 (w grupie dostosowanej do potrzeb osób dorosłych). Analizie poddano wszystkie zadania poświęcone omawianej kategorii gramatycznej wykorzystane na egzaminach certyfikatowych w latach 2009-2020. Zebrane obserwacje zestawiono z wnioskami płynącymi z opartych na thumaczeniu polsko-niemieckim i niemiecko-polskim badań nad aspektem. Dzięki uwzględnieniu perspektywy semantyki kognitywnej badania te pozwoliły na opisanie repertuaru wykładników znaczeń aspektowych w języku bezaspektowym, a w konsekwencji doprowadziły także do nowych, szczególnie istotnych z punktu widzenia glottodydaktyki polonistycznej, ustaleń w zakresie tzw. kontekstów użycia czasowników dokonanych i niedokonanych w języku polskim.
\end{abstract}

Aspekt jest kategorią gramatyczną stanowiącą wyzwanie dla glottodydaktyki polonistycznej. Ogrom literatury poświęconej dokonaności/niedokonaności czasownika, liczne spory językoznawców, wielość teorii i ujęć - wszystko to utrudnia autorom podręczników oraz nauczycielom języka polskiego jako obcego przedstawianie pewnych, wolnych od błędów i niekonsekwencji reguł dotyczących odnośnej

*beata_terka@wp.pl, Uniwersytet Jagielloński, Wydział Polonistyki, Instytut Glottodydaktyki Polonistycznej, ul. Grodzka 64, 31-044 Kraków. 
kategorii ${ }^{1}$. Obcokrajowcy (zwłaszcza z krajów niesłowiańskich), mając poczucie odmienności w zakresie wyrażania znaczeń aspektowych między swoim językiem a językiem polskim, także uznają omawiane zagadnienie za wyjątkowo trudne ${ }^{2}$. Niełatwe jest również przygotowywanie zadań sprawdzających stopień opanowania tej kategorii gramatycznej przez uczących się. Przekonanie to stanowi punkt wyjścia opisanej w niniejszym artykule analizy sposobu testowania znajomości kategorii aspektu przez zdających państwowy egzamin certyfikatowy z języka polskiego jako obcego na poziomie B1 w grupie dostosowanej do potrzeb osób dorosłych. Szczególnie interesujące wydaje się spojrzenie na zadania certyfikatowe poświęcone dokonaności/niedokonaności polskiego czasownika w świetle wniosków płynących z nowych, przeprowadzonych przez autorkę artykułu kontrastywnych badań nad aspektem, uwzględniających kognitywne ujęcie opisywanej kategorii.

\section{BADANIA KONTRASTYWNE NAD SLOWIAŃSKIM ASPEKTEM CZASOWNIKA}

\subsection{ZAŁOŻENIA I CEL BADAŃ}

Przeprowadzone badania miały charakter materiałowy, a ich bazę stanowiły testy oryginałów i tłumaczeń dwóch współczesnych powieści - polskiej i niemieckiej. Analizie poddano wszystkie występujące w wybranych tekstach formy werbalne w celu ustalenia zasad ekwiwalencji między językiem bezaspektowym (niemieckim) a językiem posiadającym gramatyczną kategorię aspektu (polskim) w zakresie wyrażania znaczeń aspektowych (Terka 2018, 2020). U podstaw opisywanych badań leżało kilka ważnych założeń. Za W. Cockiewiczem (1992, s. 80-86) przyjęto podział czasowników na cztery grupy znaczeniowe: statywne (np. mieć, lubić), procesywne (np. siwieć : osiwieć), kauzatywne (np. brudzić : pobrudzić, pisać : napisać/popisać) oraz aktywnościowe (np. stać : postać;

\footnotetext{
${ }^{1} \mathrm{Z}$ perspektywy glottodydaktycznej szczególnie ważne są poruszające zagadnienie aspektu czasownika prace A. Dąbrowskiej, M. Pasieki (2004), A. Karolczuk (2010), P. Lewińskiego (2014), M. Łazińskiego (1996, 1997, 2020).

${ }^{2}$ Warto przypomnieć choćby znaną opinię Steffena Möllera na temat aspektu polskiego czasownika:

Absurdem języka polskiego jest czasownik dokonany i niedokonany. Po pierwsze, zamiast 10 tysięcy czasownikow trzeba się nauczyć 20 tysięcy. Forma niedokonana: wczoraj robiłem zupę. Ale w końcu ja zrobiłem. Rozumiem. Dokonatem tę zupę. A teraz przyszłość: jutro będę robił zupę. Też rozumiem, że tu musi być czasownik niedokonany. Zupa się nie gotuje w ciagu minuty. Ale istnieje też druga możliwość w przyszłości: jutro zrobię zupę. Rany! Polak nie tylko ma tak bujna wyobraźnię, że widzi, jak jutro będzie stat w kuchni i gotował zupę, ale jest jeszcze pełen optymizmu, że ja zrobi! Skad wie, że jutro będzie prad? Forma dokonana to dla mnie totalny paradoks. Jak może istnieć coś dokonanego w przyszłości? (cyt. za: Seretny 2007, s. 43).
} 
krzyczeć : krzyknaćlpokrzyczeć). Leksemy należące do wyróżnionych grup łączy pewna regularność w tworzeniu partnerów aspektowych - czasowniki statywne to imperfectiva tantum, a pozostałe klasy tworzą pary aspektowe dwojakiego rodzaju: prymarne (z perfektywnym partnerem o dokonaności pełnej), dominujące w przypadku czasowników procesywnych i kauzatywnych, oraz sekundarne (z perfektywnymi odpowiednikami o dokonaności niepełnej), przeważające w klasie czasowników aktywnościowych. Te perfektywne odpowiedniki o dokonaności niepełnej to oczywiście determinatywa, które - też za Cockiewiczem (2007) - uznano za dokonane człony w sekundarnych opozycjach aspektowych. Przez różnych językoznawców są one rożnie nazywane - S. M. Dickey (2000, s. 46) na przykład traktuje je jako wirtualnych partnerów perfektywnych predykatów aktywnościowych, a H. R. Mehling (1996, za: Dickey 2000, s. 46) określa je mianem quasi-ekwiwalentów normalnych perfektywów telicznych. Czasowniki aktywnościowe są tu bowiem po prostu perfektywizowane za pomocą przedrostka po-, nadającego oznaczanej czynności determinację temporalną.

Założono także istnienie $\mathrm{w}$ językach bezaspektowych nie tylko kontekstowych wykładników aspektu, ale także wykładnika kognitywnego, czyli indykatora o charakterze niematerialnym występującego w sytuacji, w której dany czasownik zostaje użyty w swojej prymarnej kognitywnie funkcji. Wykładnik kognitywny to wskaźnik bezpośrednio odnoszący się do zaproponowanego przez R. Grzegorczykową (1997), a także - niezależnie od prac polskiej językoznawczyni - przez niemieckiego slawistę V. Lehmanna (2010), podziału czasowników na prototypowo perfektywne i prototypowo imperfektywne. W perspektywie przeprowadzonych badań szczególnie istotne były dwie grupy czasowników: prymarnie niedokonane czasowniki aktywnościowe, perfektywizowane wtórnie za pomocą przedrostka po-, oraz prymarnie dokonane czasowniki nazywające zmiany celowe, których niedokonani partnerzy profilują jedynie proces, zdarzenie w rozwoju, a nie zajście zmiany albo używani są wtedy, gdy istotne jest podkreślenie powtarzalności zdarzenia.

Analiza konkretnego materiału miała pozwolić na ustalenie pełnego repertuaru wykładników znaczeń aspektowych i ich wzajemnych proporcji w języku pozbawionym omawianej kategorii gramatycznej, a także potwierdzić istnienie w języku polskim kontekstów umożliwiających wymienność partnerów aspektowych oraz doprowadzić do próby ich opisania i uporządkowania.

\subsection{WNIOSKI}

Przeprowadzone badania materiałowe pokazują, że wykładnik kognitywny jest dominującym indykatorem znaczeń aspektowych w pozbawionym tej gramatycznej kategorii języku niemieckim. Wnioski płynące z badań empirycznych 
nie potwierdzają zatem powszechnego dotychczas przekonania o decydującej roli wykładników kontekstowych we wskazywaniu na dokonaność lub niedokonaność czasownika użytego w tekście napisanym w języku bezaspektowym³ ${ }^{3}$. Rola kontekstu okazuje się bowiem relatywnie niewielka. Stanowi on samodzielny indykator aspektu wyłącznie w sytuacjach, w których w tekście użyty zostaje niedokonany partner czasownika prymarnie perfektywnego (np. otwierać zamiast otworzyć, kupować zamiast kupić etc.). Jeśli zaś czasownik występuje w swojej kognitywnie prymarnej funkcji, żaden materialny wykładnik aspektu nie jest w tekście w języku bezaspektowym konieczny, by thumacz na język polski poprawnie zidentyfikował perfektywność bądź imperfektywność danej formy werbalnej. Oznacza to, że i w języku polskim wskaźniki kontekstowe nie determinują wyboru właściwego partnera aspektowego w takim stopniu, w jakim zwykło się uważać, co może mieć duże znaczenie dla glottodydaktyki polonistycznej ${ }^{4}$.

Badania oparte na thumaczeniach potwierdzają także istnienie sytuacji, w których wyrażenie danej opozycji aspektowej, choć obligatoryjne w języku słowiańskim, wcale nie jest konieczne. Zjawisko irrelewancji aspektu, pozwalające na zastąpienie jednego partnera aspektowego drugim bez wprowadzania istotnej zmiany znaczenia, wcale nie należy do rzadkości.

Mając na uwadze przytoczone powyżej wnioski płynące $\mathrm{z}$ badań empirycznych, warto przyjrzeć się zadaniom służącym testowaniu znajomości kategorii aspektu w państwowych egzaminach certyfikatowych z języka polskiego jako obcego.

\section{KATEGORIA ASPEKTU W PAŃSTWOWYCH EGZAMINACH CERTYFIKATOWYCH Z JEZZYKA POLSKIEGO JAKO OBCEGO}

\subsection{DANE LICZBOWE}

Analizie poddano zadania poświęcone kategorii aspektu we wszystkich państwowych egzaminach certyfikatowych z języka polskiego jako obcego dla osób dorosłych na poziomie B1 z dwunastu lat - od roku 2009 do 2020. W wybranym przedziale czasowym wykorzystano łącznie 21 różniących się treścią zadań testu-

${ }^{3} \mathrm{O}$ dominującej roli kontekstowych wykładników znaczeń aspektowych w języku niemieckim piszą między innymi: T. Czarnecki (1998), J. A. Czochralski (1975) i A. Nadachewicz (2007).

${ }^{4}$ Rolę wskaźników kontekstowych w wyborze właściwej formy aspektowej zgodnie podkreślają podręczniki do nauczania języka polskiego jako obcego, o zasadniczym znaczeniu kontekstu pisze także miedzy innymi A. Karolczuk (2010). 
jących znajomość odnośnej kategorii gramatycznej. Wszystkie były zadaniami wyboru, wymagającymi wskazania poprawnej formy. W 2017 roku zmianie uległa formuła testowania znajomości aspektu - zrezygnowano z osobnego zadania poświęconego wyłącznie tej kategorii i połączono ją z kategorią trybu.

W przeanalizowanym materiale $\mathrm{z}$ owych dwunastu lat pojawiło się 116 różnych czasowników / par czasowników, co oznacza, że na jedno zadanie poświęcone aspektowi przypadło średnio 5,5 czasownika na 11 luk w tego typu jednostce testowej (badanie uwzględniło bowiem także przykład obecny w każdym zadaniu). W poddanych analizie tekstach wystąpiło 57 par aspektowych, w których wykładnikiem perfektywności jest sufiks fleksyjny (przy czym to określenie umownie obejmuje zarówno przyrostek tematyczny, jak i alternacje w temacie czasownika), 24 pary prefiksalne, 11 par z supletywnym wykładnikiem aspektu, 10 sekundarnych par aspektowych (z partnerem dokonanym tworzonym za pomocą przedrostka po- od czasownika aktywnościowego), 8 czasowników statywnych oraz 6 par błędnie utworzonych. 82 razy wymagano od zdających wyboru czasownika niedokonanego, 123 razy czasownika dokonanego, 20 razy - od czasu połączenia kategorii aspektu z kategorią trybu - rozpoznawanie poprawnej struktury dotyczyło czasowników statywnych, a w 8 przypadkach pytano o partnera aspektowego $\mathrm{z}$ błędnie utworzonej opozycji aspektowej.

\subsection{ROLA KONTEKSTU}

W poddanych analizie zadaniach w zdecydowanej większości przypadków na konieczność wyboru perfektywnej bądź imperfektywnej formy wskazuje kontekst. Autorzy zadań bardzo chętnie wykorzystują kontekst nawet wtedy, gdy w tekście dany czasownik występuje w swojej kognitywnie prymarnej funkcji. Kontekstowe podpowiedzi pojawiają się zatem zarówno w sytuacjach wymagających użycia formy dokonanej czasownika nazywającego zmianę celową lub niecelową (przykłady (1) i (2)), jak i w sytuacjach wymagających użycia prymarnie przecież niedokonanego czasownika aktywnościowego (przy$\operatorname{kład}(3))$.

(1) Wczoraj na urodziny Pawet (dostawat/dostat) od koleżanek oryginalny prezent.

(2) Pawet szybko (otwierat/otworzyt) pudetko.

(3) Dziś rano Antoni dlugo (szukat/poszukat) kluczyków do samochodu.

Wykorzystane w zadaniach grupy kontekstów sugerujące dokonaność lub niedokonaność użytych w tekście czasowników układają się względnie symetrycznie po stronie perfektywności i imperfektywności, tworząc wyraźne opozycje. 
Tabela 1. Konteksty sugerujace aspekt czasownika w zadaniach certyfikatowych

\begin{tabular}{|l|l|}
\hline \multicolumn{1}{|c|}{ Aspekt niedokonany } & \multicolumn{1}{c|}{ Aspekt dokonany } \\
\hline $\begin{array}{l}\text { rozciągłość w czasie, procesualność } \\
\text { od dtuższego czasu, długo, ciągle, przez (go- } \\
\text { dzinę/tydzień/rok) }\end{array}$ & $\begin{array}{l}\text { punktowość, momentalność } \\
\text { w tym/tamtym momencie, już o szóstej, już na } \\
\text { samym początku, szybko, nagle, od razu }\end{array}$ \\
\hline $\begin{array}{l}\text { powtarzalność } \\
\text { w każdej wolnej chwili, w każde wakacje, co } \\
\text { wieczór, zawsze, zwykle, systematycznie, co- } \\
\text { dziennie, często }\end{array}$ & $\begin{array}{l}\text { jednorazowość } \\
\text { wczoraj, miesiac temu, pewnego roku, po raz } \\
\text { pierwszy w życiu, w tym tygodniu }\end{array}$ \\
\hline $\begin{array}{l}\text { równoczesność } \\
\text { szerszy kontekst zdania lub szeregu zdań) }\end{array}$ & $\begin{array}{l}\text { najpierw..., a potem; wreszcie, w końcu, kiedy } \\
\text { już, kiedy (po tym jak...), po chwili }\end{array}$ \\
\hline
\end{tabular}

Źródło: opracowanie własne

Wśród kontekstów wskazujących na aspekt czasownika, a niepozwalających się zestawić $\mathrm{w}$ parę opozycji, w poddanym analizie materiale pojawiają się także: w przypadku niedokonaności - habitualność (dawniej + szerszy kontekst wypowiedzi), zaś w przypadku dokonaności - zakończenie czynności, obecność rezultatu (cały, wszystkie, udało się...).

Testowanie znajomości aspektu na poziomie B1 uzasadniają standardy wymagań egzaminacyjnych, stanowiące załącznik do rozporządzenia Ministra Nauki i Szkolnictwa Wyższego z dnia 26 lutego $2016 \mathrm{r}^{5}{ }^{5} \mathrm{~W}$ zadaniach poświęconych kategorii aspektu wskaźniki kontekstowe występują naprawdę często. Proponowane teksty (i konteksty) są spójne z tymi, które uczący się na poziomach zaawansowania językowego A1-B1 znajdują w dostępnych na rynku podręcznikach oraz innych materiałach dydaktycznych do języka polskiego jako obcego. Przytaczane w nich konteksty użycia czasowników dokonanych i niedokonanych układają się w większości zbieżne z podanymi powyżej pary opozycji.

Tabela 2. Najważniejsze konteksty użycia partnerów aspektowych w podręcznikach do języka polskiego jako obcego (poziomy A1-B1)

\begin{tabular}{|l|l|}
\hline \multicolumn{1}{|c|}{ Aspekt niedokonany } & \multicolumn{1}{c|}{ Aspekt dokonany } \\
\hline rozciągłość w czasie, procesualność & punktowość, momentalność \\
\hline powtarzalność, regularność & jednorazowość \\
\hline $\begin{array}{l}\text { brak zakończenia, brak rezultatu, koncentracja } \\
\text { na procesie }\end{array}$ & zakończenie, rezultat \\
\hline akcje równoczesne & akcje chronologiczne \\
\hline
\end{tabular}

Źródło: opracowanie własne

${ }^{5} \mathrm{https}: / / w w w . i n f o r . p 1 / a k t-p r a w n y / D Z U .2016 .061 .0000405$,rozporzadzenie-ministra-nauki-i-szkolnictwa-wyzszego-w-sprawie-egzaminow-z-jezyka-polskiego-jako-obcego.html (dostęp: 20.07.2021). 
W świetle zaprezentowanych wcześniej wyników badań empirycznych można jednak powiedzieć, że w zadaniach sprawdzających znajomość aspektu wskaźników kontekstowych jest za dużo; że często są one niepotrzebne. Co więcej, utrwalają pewne fałszywe przekonania na temat zasad rządzących wyborem partnerów aspektowych, zwłaszcza czasowników dokonanych. Niesłusznie bowiem przypisuje się nazywanej przez te czasowniki czynności jednorazowość, punktowość (rozumianą jako konkretny moment w czasie) czy umiejscowienie w sekwencji następujących po sobie wydarzeń jako cechy wymuszające perfektywność użytej do opisu rzeczywistości pozajęzykowej formy werbalnej.

\subsection{FAŁSZYWE PARY ASPEKTOWE}

W stanowiącym podstawę przeprowadzonych badań materiale aż osiem razy pytano o partnera aspektowego błędnie utworzonej pary aspektowej. W analizowanych zadaniach egzaminacyjnych pojawiło się sześć takich fałszywych opozycji:

(1) cieszyć się : ucieszyć się

(2) denerwować się : zdenerwować się

(3) mieszkać : zamieszkać

(4) nudzić się : znudzić się

(5) rozumieć : zrozumieć

(6) pamiętać : zapamiętać

Większość przytoczonych przykładów reprezentuje występujące w glottodydaktyce polonistycznej zjawisko błędnego uznawania za perfektywnych partnerów czasowników statywnych lub aktywnościowych takich leksemów werbalnych, które pozbawione są odpowiedników niedokonanych, a zatem należą do klasy perfectiva tantum. Zdarza się też, jak w przypadku czasownika z przykładu (6), że partner dokonany z błędnie utworzonej pary aspektowej ma swój prawdziwy imperfektywny odpowiednik (zapamiętywać : zapamiętać).

\subsection{KATEGORIA ASPEKTU A KATEGORIA TRYBU}

Od czasu połączenia testowania znajomości aspektu ze sprawdzaniem stopnia opanowania kategorii trybu w ramach egzaminu certyfikatowego na poziomie B1 umiejętności wyboru właściwego partnera aspektowego wymaga się od zdających niezwykle rzadko. W dziewięciu zadaniach przygotowanych już według nowych zasad piszący staje przed koniecznością wyboru jednej z trzech podanych w nawiasie form. Sytuacji, w których wśród tych form dwie różnią się jedynie 
aspektem, jest siedemnaście, z czego osiem dotyczy podanych przez autorów zadań przykładów. Oznacza to, że umiejętności rozpoznawania aspektu oczekuje się od piszących dziewięć razy - średnio raz na test, podczas gdy każde z zadań opisywanego typu pozwala na zdobycie pięciu punktów (10 x 0,5p.). Zdający mogą zatem za opanowanie niezwykle ważnej przecież kategorii aspektu uzyskać maksymalnie pół punktu na danym egzaminie. O pozostałych decyduje znajomość kategorii trybu, czasu i/lub osoby. W przytoczonym poniżej zadaniu opisywanego typu znajomości aspektu nie sprawdza się na przykład w ogóle - różnica czysto aspektowa pojawia się wyłącznie w jednym z przykładów (jeśli pominiemy błędnie utworzoną parę aspektową pamiętać : zapamiętać) i dotyczy czasownika aktywnościowego:

Tomek i Mateusz sq braćmi. Tomek często wspomina ich wspólna decyzję sprzed lat: „I ty, i ja (pamietajmy, zapamiętajmy, niech pamiętaja) ${ }^{P R Z Y K L A D}$, ze (gdybym, gdybyś,

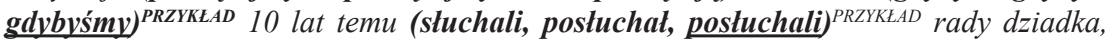
dziś (byliśmy, bylibyśmy, byli)l pilotami”. Mateusz odpowiedziat: „, Gdybym tylko wtedy (wiedzial, wiedziatem, wiedzieli) ${ }^{2}$, co planuje dziadek...". Chtopcy dopiero zaczynali liceum i bardzo interesowali się lotnictwem. Gdyby (mogli, mogły, mogliby) ${ }^{3}$, spędzaliby całe dnie na lotnisku, (poznawatyby, poznaj, poznawaliby) ${ }^{4}$ samoloty i pilotów. Pewnego dnia dziadek powiedziat do nich obu: „(Kończyliby, Skończcie, Skończ) jak najlepiej liceum $i$ (pojedź, jedźcie, pojechaliby) ${ }^{6}$ na studia do Kanady. Ja wam dam pieniadze". Chłopcy roześmiali się i powiedzieli: „,Dziadku, nie (żartuj, zażartowałbyś, zażartujcie)?! Skad (weź, brałby, wziątbyś) ${ }^{8}$ tyle pieniędzy? "' Gdyby wtedy (traktowaliśmy, potraktowali, potraktowaliby) $)^{9}$ stowa dziadka poważnie, to dziś ich kariery zawodowe (wygladajmy, wygladałby, wygladałyby) ${ }^{10}$ inaczej. Dużo później okazało się, że dziadek całe życie oszczędzal, żeby zrealizować ich marzenia ${ }^{6}$.

Warto przyjrzeć się uważnie tym dziewięciu zdaniom stanowiącym podstawę czysto aspektowego zadania. W siedmiu z nich mamy do czynienia z aspektem czasownika w trybie rozkazującym (w tym jeden raz wybór dotyczy partnera z fałszywej opozycji pamiętać : zapamiętać), w dwóch pozostałych - z aspektem czasownika w trybie przypuszczającym.

(1) Nie (popatrz, patrzysz, patrz) na to tak pesymistycznie!

(2) Mikołaju, nic mi nie (powiedz, powiedziałbyś, mów) o Internecie!

(3) Mój drogi, nie (zastanawiaj się, zastanów się, zastanowiłbyśs się) dłużej!

(4) Nie macie w szafie koszulki z nadrukiem? (Kupujcie, Kupuj, Kupcie) ja koniecznie!

(5) Proszę was, (pamiętajcie, pamiętalibyśmy, zapamiętajcie) o naszym dziadku. Trzeba mu pomóc wyremontować dom.

(6) Najpierw (mów, powiedz, mówiłbyś) mi, jaki zawód cię interesuje?

(7) Tato, (ugotujcie, gotuj, ugotuj) znowu ten pyszny rosót na obiad!

(8) Już na samym początku pojawity się problemy: mój mąż nie (wziątby, bratby, weź) naszych paszportów, gdyby nie moja matka.

(9) Tata nie (rozkazałby, rozkazywałby, niech rozkazuje) mi codziennie.

${ }^{6}$ Tekst zadania pochodzi z testu przykładowego z roku 2019 zamieszczonego na stronie certyfikatpolski.pl: https://certyfikatpolski.pl/wp-content/uploads/2019/09/B1_test.pdf (dostęp: 25.07.2021). 
W formach zaprzeczonych trybu rozkazującego najczęściej używamy czasowników niedokonanych (przykłady (1), (2) i (3)). Uczących się języka polskiego jako obcego informują o tym podręczniki oraz inne materiały dydaktyczne. Dla zdających jest to zatem gramatyczny kontekst, który w zasadzie nie wymaga namysłu nad wyborem poprawnej formy. Użycia aspektu dokonanego wymagałyby zdania typu: Nie zjedz całego ciasta!, Nie zrób jakiegoś błędu!. Tego typu wypowiedzeń trudno jednak oczekiwać od zdających egzamin na poziomie B1. W formach niezaprzeczonych trybu rozkazującego natomiast wybór w przypadku prototypowych par aspektowych pada najczęściej na partnera perfektywnego (przykłady (4), (6) i (7)). Wraz ze zmianą formy dokonanej na niedokonaną zmienia się bowiem ton wypowiedzi - staje się on bardziej zdecydowany, wyraża także zniecierpliwienie ${ }^{7}$. W przypadku sekundarnych par aspektowych z niedokonanym partnerem aktywnościowym (np. czekać : poczekać, słuchać : postuchać, rozmawiać : porozmawiać) w trybie rozkazującym często mamy z kolei do czynienia z wymiennością partnerów aspektowych, czyli sytuacją, w której możemy użyć zarówno formy perfektywnej, jak i imperfektywnej bez wprowadzania istotnej zmiany znaczenia danej wypowiedzi. Różnice w wyrazie emocjonalnym między użyciem form dokonanych i niedokonanych w trybie rozkazującym zaznaczają się mniej wyraźnie w przypadku czasowników nietworzących właściwych opozycji aspektowych.

Zarówno wrażliwość na zabarwienie emocjonalne wypowiedzi, jak i świadomość istnienia kontekstów wpływających na irrelewancję aspektu wymagają jednak naprawdę dobrej znajomości języka polskiego oraz osłuchania z nim w stopniu wykraczającym poza wymagania stawiane przystępującym do egzaminu na poziomie B1. Dlatego też autorzy zadań egzaminacyjnych nie sięgają po tego typu przykłady. W związku z tym także w przypadku niezaprzeczonych form trybu rozkazującego wybór poprawnej, czyli dokonanej, formy aspektowej jest dla zdających dość oczywisty.

W trybie przypuszczającym natomiast wybór między dokonanością a niedokonanością czasownika nie jest zadaniem łatwym. Częste są bowiem sytuacje, w których w ramach omawianej struktury gramatycznej możemy zastąpić jednego partnera $\mathrm{z}$ danej pary aspektowej drugim. W wypowiedzeniach $\mathrm{w}$ trybie warunkowym semantyczne przeciwstawienie niedokonaności i dokonaności nie odgrywa roli pierwszoplanowej. Są one pozbawione odwołania do konkretnej aktywności czy umiejscowionego w czasie zdarzenia, którego przedstawienie jako zakończonego lub trwającego, powtarzającego się bądź jednorazowego byłoby z punktu widzenia znaczenia przekazu naprawdę konieczne ${ }^{8}$. Tryb przypuszczający

${ }^{7}$ W. Śmiech (1970, s. 130) to wrażenie wyrażanego przez czasownik imperfektywny większego nacisku wywodzi z bardziej aktualnego znaczenia form niedokonanych.

${ }^{8}$ Por. rozważania E. Koschmiedera na temat „faktów bez wartości miejscowej” (1934, s. 32-96) oraz C. Piernikarskiego na temat substantywów dewerbalnych (1969, s. 92). 
otwiera pole do wymienności partnerów aspektowych zdecydowanie częściej niż tryb orzekający, którego referencja do „prawdziwej” akcji znacznie ogranicza pole do konkurencji aspektu9 ${ }^{9}$. Nie dziwi więc fakt, iż jedynie w dwóch przykładach wymagających wyboru poprawnej formy trybu warunkowego autorzy zadań decydują się na wykorzystanie jako potencjalnych odpowiedzi dwóch form czasownikowych różniących się wyłącznie aspektem (przykłady (8) i (9)). W wielu innych przykładach, z których warto przytoczyć choć kilka, to właśnie konkurencja aspektu uniemożliwia takie rozwiązanie (przykłady (10) - (13) poniżej).

(10) Gdybym była toba, też pewnie (ogladałabym, ogląatby, obejrzatbyś) wiele ogłoszeń.

(11) Nie (kupiłabym, kupiłam, kupowałam) mebli, gdybym wcześniej nie mogła ich obejrzeć.

(12) Gdyby mogli, spędzaliby całe dnie na lotnisku, (poznawatyby, poznaj, poznawaliby) samoloty i pilotów.

(13) Nie bójcie się, że poczujecie się, jakbyście (pokazywali, pokazywaliście, pokazywalibyście) catemu światu wasze opinie i poglady.

Różnice aspektowe zaznaczają się najwyraźniej w zdaniach oznajmujących. Tych natomiast jest $\mathrm{w}$ poddanych analizie zadaniach nowego typu niewiele, co prawdopodobnie wynika $\mathrm{z}$ istnienia osobnej jednostki testowej poświęconej gramatycznej kategorii czasu - zadania opartego na tekście napisanym właśnie w trybie oznajmującym. Tam jednak znajomości aspektu już się nie sprawdza.

\subsection{PODSUMOWANIE}

W świetle wniosków płynących z przeprowadzonej analizy zadań egzaminacyjnych, rozpatrywanych na tle najnowszych ustaleń dotyczących kategorii aspektu w perspektywie semantyki kognitywnej, można stwierdzić, że zadania te powielają schematy obecne w podręcznikach i innych materiałach dydaktycznych dla cudzoziemców uczących się języka polskiego. Kładą szczególny nacisk na znaczenie kontekstu dla wyboru odpowiedniego partnera aspektowego. Nie odwołują się do kognitywnego uprzywilejowania perfektywnego lub imperfektywnego członu danej opozycji aspektowej. W zadaniach starego typu, gdzie znajomość odnośnej kategorii gramatycznej testowana jest jako osobne zagadnienie, umiejętnie unikają kontekstów wpływających na irrelewancję aspektu, jednak w nowej formule, w której perfektywność/imperfektywność czasownika zestawiona jest z kategorią trybu, autorzy zadań wpadają w pułapkę owej irrelewancji, co widać w oczekiwaniu od zdających wyboru odpowiedniej formy najczęściej w oparciu o poprawne zidentyfikowanie osoby, czasu lub właśnie trybu, a nie aspektu użytego czasownika.

\footnotetext{
${ }^{9}$ Tę właściwość indykatywu podkreśla C. Piernikarski (1969, s. 92).
} 


\section{WYZWANIA I PERSPEKTYWY}

Potrzeba refleksji nad sposobem testowania znajomości kategorii aspektu (a potencjalnie także innych kategorii gramatycznych) została wzmocniona przez wyzwanie, przed jakim staje nauczanie i testowanie w ogóle, w tym także certyfikacja języka polskiego jako obcego. Próba przeniesienia nauczania i egzaminowania do przestrzeni cyfrowej podyktowana została koniecznością związaną z pandemią koronawirusa. Niezależnie jednak od niej testowanie w formule zdalnej i on-line jest raczej nieuniknioną, a przez wielu też wyczekiwaną przyszłością. Chociaż niesie ze sobą określone trudności i wyzwania, związane zwłaszcza z rozwiązaniami technicznymi, otwiera także wiele możliwości, pozwalając na poświadczanie poziomu biegłości w języku polskim w prawdziwie masowej skali i uniezależniając organizatorów oraz kandydatów od konkretnego, wspólnego dla wszystkich, czasu i miejsca egzaminu. Okres dostosowywania zadań certyfikatowych do potencjalnego nowego medium jest również dobrym momentem na ponowne otwarcie dyskusji nad konstrukcją poszczególnych modułów egzaminu ${ }^{10}$. Z pewnością warto na nowo przemyśleć zestawy kategorii gramatycznych testowanych wspólnie w ramach jednego zadania, a w odniesieniu do poruszanego w niniejszym artykule zagadnienia - rozważyć odejście od sprawdzania znajomości aspektu w połączeniu z samymi trybami.

\section{BIBLIOGRAFIA}

Cockiewicz W., 1992, Aspekt na tle systemu słowotwórczego polskiego czasownika i jego funkcyjne odpowiedniki w języku niemieckim, Kraków.

Cockiewicz W., 2007, Na peryferiach aspektu, „LingVaria”, 2 (4), s. 9-25.

Czarnecki T., 1998, Aspektualität im Polnischen und Deutschen. Bedeutungen und Formen in einer konfrontativen Übersicht, Gdańsk: Wydawnictwo Uniwersytetu Gdańskiego.

Czochralski J.A., 1975, Verbalaspekt und Tempussystem im Deutschen und Polnischen. Eine konfrontative Darstellung, Warszwa.

Dąbrowska A., Pasieka M., 2004, Wybrane zagadnienia morfologii czasownika jako problem glottodydaktyczny, w: M. Wojtak, M. Rzeszutko, $W$ kręgu wiernej mowy, Lublin, s. 513-528.

Dickey S.M., 2000, Parameters of Slavic Aspect: A Cognitive Approach, Stanford.

Grzegorczykowa R., 1997, Nowe spojrzenie na kategorię aspektu w perspektywie semantyki kognitywnej, w: R. Grzegorczykowa, Z. Zaron (red.), Semantyczna struktura stownictwa i wypowie$d z i$, Warszawa, s. 25-38.

Karolczuk A., 2010, Teksty, „podteksty” i konteksty a przyswajanie aspektu, „Acta Universitatis Lodziensis. Kształcenie Polonistyczne Cudzoziemców”, nr 17, s. 251-256.

${ }^{10}$ Trwają prace nad projektem egzaminów certyfikatowych w wersji komputerowej i on-line. Jest on jednak dopiero w fazie początkowej-obmyślania koncepcji, technicznych oraz prawnych rozwiązań. Wprowadzenie tych wstępnych pomysłów w życie z pewnością nie stanowi scenariusza możliwego do zrealizowania w najbliższej przyszłości, jednak bez wątpienia jest to kierunek zmian, który należy brać pod uwagę w namyśle nad dalszym rozwojem certyfikacji języka polskiego jako obcego. 
Koschmieder E., 1934, Nauka o aspektach czasownika polskiego w zarysie. Próba syntezy, Wilno.

Lehmann V., 2010, Der slavische Aspekt im Licht der kognitiven Linguistik, w: T. Anstatt, B. Norman (red.), Die slavischen Sprachen im Licht der kognitiven Linguistik, s. 77-99.

Lewiński P., 2014, Istota aspektu a nauczanie języka polskiego jako obcego, w: A. Dąbrowska, U. Dobesz (red.), 40 lat wrocławskiej glottodydaktyki polonistycznej. Teoria i praktyka, Wrocław, s. 313-329.

Łaziński M., 1996, Bezokolicznik czasownika dokonanego jako człon wymagany w zdaniu, „Poradnik Językowy", nr. 1, s. 21-29.

Łaziński M., 1997, Opozycja czasowników mówić-powiedzieć w języku polskim. Analiza leksykalna i aspektowa, w: . R. Grzegorczykowa, Z. Zaron (red.), Semantyczna struktura słownictwa $i$ wypowiedzi, Warszawa, s. 121-147.

Łaziński M., 2020, Wykłady o aspekcie polskiego czasownika, Warszawa.

Nadachewicz A., 2007, Kategoria aspektu w języku polskim i niemieckim. Analiza translatywna, „Investigationes Linguisticae”, vol. XV, Poznań, s. 129-152.

Piernikarski C., 1969, Typy opozycji aspektowych czasownika polskiego na tle stowiańskim. Wrocław-Warszawa-Kraków.

Seretny A., 2007, Kto czyta - nie błądzi, Kraków.

Śmiech W., 1986, Derywacja prefiksalna czasowników polskich, Wrocław - Warszawa - Kraków - Gdańsk.

Terka B., 2018, Aspekt polskiego czasownika jako problem przekładu oraz wyzwanie dla uczacych się i nauczajacych języka polskiego jako obcego, „Acta Universitatis Lodziensis. Kształcenie Polonistyczne Cudzoziemców", nr 25, s. 87-95.

Terka B., 2020, Badania kontrastywne nad aspektem polskiego czasownika a glottodydaktyka polonistyczna, w: M. Biernacka, I. Janowska (red.), Kierunki badań w glottodydaktyce polonistycznej, Kraków, s. 173-187.

https://certyfikatpolski.pl/o-egzaminie/przykladowe-testy-zbiory-zadan/, (dostęp: 25.07.2021).

https://certyfikatpolski.pl/wp-content/uploads/2019/09/B1_test.pdf, (dostęp: 25.07.2021).

https://www.infor.pl/akt-prawny/DZU.2016.061.0000405, rozporzadzenie-ministra-nauki-i -szkolnictwa-wyzszego-w-sprawie-egzaminow-z-jezyka-polskiego-jako-obcego.html, (dostęp: 20.07.2021).

Beata Terka

\section{THE WAY OF TESTING THE LEVEL OF MASTERY OF THE POLISH VERB ASPECT IN THE STATE CERTIFICATE EXAMINATIONS IN POLISH AS A FOREIGN LANGUAGE AT THE B1 LEVEL IN THE LIGHT OF NEW RESEARCH ON PERFECTIVENESS/IMPERFECTIVENESS OF VERBS}

Keywords: verb aspect, certificate examinations, grammatical correctness, contextual indicator, interchangeability of aspectual partners

Summary. The article concerns the testing of the level of mastery of the Polish verb aspect in state certificate examinations in Polish as a foreign language at the B1 level (adjusted to the needs of adults). All the tasks (from the years 2009 - 2020) devoted to the discussed grammatical category were analysed. The collected observations were compared with the conclusions drawn from the research on aspect based on Polish-German and German-Polish translation. By taking into account the perspective of cognitive semantics, this research allowed the description of the repertoire of exponents of aspectual meanings in non-aspect language, and consequently led to new findings in the field of the so-called contexts of the use of perfective and imperfective verbs in Polish - findings particularly important from the point of view of teaching Polish as a foreign language. 